\title{
Marketing: Farmers Promulgates Cash Crops, Itinerary to Support Their Livelihood and Enhance Their Living Standard
}

\author{
Onessimos Shangdiar \\ University of Science and Technology Meghalaya, India
}

\begin{abstract}
This paper is a briefing on the marketing and emergence of cash crops in the Indo-Bangladesh border, South West Khasi Hills District Meghalaya. It is solely aimed at understanding the inborn entrepreneurship skills of the particular sub-tribe of the Khasis called "War". They live in steep and sloppy mountains with moderate temperatures and receive sufficient precipitation throughout the year, which enables them to sustain their farming.

Marketing is the heart core of every individual, regardless of any background and professionals. Marketing plays a very important role to the farmers, and everyone could enhance their standard of living due to the technique of commercialization. The Non-farmers can buy the food crops from the farmers through the role of business administration. It is pointless to have money without having a food supply. Thus, the commercialization of agricultural produce is highly required.

Cash crops cultivation promotes economic growth and social growth; economically, people can generate income, put savings, and purchase physical capital. Socially they bridged with each other, helping one another, exchanging work, advising the younger ones, and imparting knowledge to one another, providing seeds and saplings to the have not. There is an evolution from practicing traditional crops, which can be consumed directly, to Cash crops, which need to be exported outside of the State through a marketing system with the intention to manufacture further for finished products.
\end{abstract}

Keywords: Marketing; Cash Crops; Horticulture; Ri-War (border area); Barter system; Entrepreneurship; Farmers

This is an open access article under the CC-BY-NC license.

\section{INTRODUCTION}

Horticultural commercialization is defined as the proportion of horticultural products that can be marketed. There is a transition from subsistence farming to commercial-oriented farming, and the reason is due to the accessibility to the markets where it offers surplus and generates income to the family to exercise the financial capital for other purposes (C. Babu, 2009). In this paper, I am focusing on a particular Block Development, that is C \& RD block Mawkyrwat, where the "War Maram" is located. The major crops practicing in this region are black pepper, orange, bay leaf, broomstick, areca nut, betel vine, tapioca, and other crops suitable to the weather. Hence, the State Government did not recognize their crops as cash crops until 31st May 2019; therefore, prior to that, no governmental aid was being provided to the farmers, and tax was being collected from them. Transportation is another challenge for the farmers; there is no road access to their farms. Physically they have to carry their produce from farm to their house and from house to market. Besides that, they also carry sick persons, including pregnant women using bamboo chairs and

Corresponding author

Onessimos Shangdiar, onessimoss@gmail.com

DOI: https://doi.org/10.31098/jsetp.v1i2.570

Research Synergy Foundation 
other tools to reach the station where vehicles are available. The price of the produce degrading due to labour cost; they need workers on the farm and the ones who will carry to the market. The lacking of market standard is another confrontation to the people; intermediary and small business suppliers were pressing down the price from farmers. Skills and Technology is an added hindrance where people cannot access; higher authorities like government and non-government sectors need to widen their scope and reach out to the marginalized farmers.

Due to the topography, the people could not practice agricultural farming example growing Rice, Potato, Tomato, Cabbage, and other vegetables, and they had to purchase those items from the market. Therefore to buy Rice, Potato, and other vegetables, they have to sell their horticulture produce. After attaining surplus from horticulture produce then they diversify the financial capitals for other purposes.

Approximately it has been 60 years where people in the region started commercializing their produce. Farmers toiling day and night thinking about better produce and profitable sale, the researcher is very much content to understand the outcome of cash crops practicing by the people of Ri-war in day-to-day life.

Marketing of horticulture produce in the region creates curiosity to the researcher to know more about it. The researcher is aware that, prior to cash crops farming, there was subsistence practice, and even a barter system took place where people initially focused on food crops like Yam, Tapioca, Banana, Orange, and other citrus fruits. Farmers slowly abandoned those crops and shifted to broom grass, bay leaf, and wild black pepper since they could easily commercialize and export.

Now, the domain concerns are:

1. Will cash crops sustain their livelihood?

2. Do people understand the value of indigenous farming?

3. What is the impact of cash crops on the environment and lifestyle of the farmers?

\section{LITERATURE REVIEW}

\section{Cash crops}

Cash crops have been distinguished into two types, that is, non-food crops or indirect consumption produce and the food produce which can be consumed directly. All the plantation crops are used for commercializing even though there is a categorization and preferable option where the farmers decided to sell or for self-consumption. Most of the crops in developed countries are cultivated for revenue. Likewise, the developing countries pay heed to the market system and adopt the crops which can be commercialized effectively. For example, if the onion price is good and the potato price is bad, the farmers will invest more in onion farming rather than potatoes.

Learning about the farmers' background of commercialization in Ri-War is lacking behind in utilizing innovative ideas for their natural products to do business. There is no diversification of ideas for value addition or modification of products to attract the customers; what they get from their farm, they sell as it is. Even though they engaged in commercializing their crops but their interest is in farming, not business expanding. They are passionate about their own profession and content to be primary producers. 


\section{Cash Crops Evolution}

There is no doubt that commercial crops have contributed a lot to economic growth, and this has happened since the 19th century. Since then, a series of development sprouted through the proposition of commercial crops; the following are the major causes;

\section{The introduction of the money economy}

Trade and money was existed since the time of the Mughal Empire; as soon as the cash economy was introduced barter system or payment in kind got wiped out. The British company asked the people of India to pay the land revenue in cash, as they did not accept any more in kind. Thus, it compelled the farmers to sell some of their produce in order to get money; slowly, it became habituated, and they found that money is a catalyst it can make use for any purpose; this pattern encourages them to start selling their produce. Merchants existed, took advantage of the indebtedness of the farmers and asked them to give their crops in return, and then started doing business. Thus, the concurrent commercialization started from the enthusiastic business class people who later became indispensable to exploit the farmers. To meet the needs and bear the expense charged by the landlord, the farmers understood the reputation of cash crops rather than food crops; for example, in 1860-61 farmers shifted from grain farming to cotton production (Sharma, 2019).

\section{Ease of means of communication}

Monetization would not have been effective until the mode of communication was efficient, for instance, transportation, available of road and railway track, ship, Aeroplane, the establishment of bank and development of media. Through these means of communication, farmers got to supply their produce to different states and even internationally. British rulers constructed railway tracks to ease the transportation of cotton from India; while constructing the railway track; there was a supply of food to the workers where the British paid the food crops from Indian farmers. Suez Canal was also opened in 1869 where they could export the raw material through ships, however, they bought at a very low rate. The advance the transportation the decline is the cost of transportation, therefore apart from cotton, they also export rice and wheat (Sharma, 2019).

\section{The US Civil War}

The American civil war that took place in 1861-65 marked another milestone of commercial crops. As the USA plunged into the civil war, the British demanded to transfer the raw cotton from America to India. Towards the end of the civil war, the supply of raw cotton was decline, yet some other raw material to export was added like jute, food grains, and oilseeds. The proportion towards commercialization started to accelerate; however, not all types of crops have the same story of developing. In the year between 1860 and 1890 different prominent spots for marketing emerged, for instance, Bombay presidency 13 for cotton, jute in Bengal, sugarcane in United Provinces, and groundnut in Madras. Since then, cash crops production overtook food production with a growth rate. Thus the production of commercial crops boasts the economy in terms of marketing, processing, and production (Sharma, 2019). 
Journal of Social Entrepreneurship Theory and Practice (JSETP), Vol. 1 (2), 1-13

Marketing: Farmers Promulgates Cash Crops, Itinerary to Support Their Livelihood and Enhance Their

Living Standard

Onessimos Shangdiar

\section{Phases of Agriculture Commercialization in India}

There are three phases of agriculture commercialization, these are:-

Phase I: the first form was associated with the agriculture plantation where the farmers could commercialize the product, and that was tea plantation in the Northern District of Bengal.

Phase II: The second phase was the practice of subsistence commercialization or the jute phase. Under this type of commercialization, farmers who depend on subsistence crops turn to intensive cash crops, and it happened in the late 19th and early 20th centuries.

Phase III: The third form of agriculture commercialization was dependent on the commercialization of the late 18th and 19th centuries. This phase was characterized by the contract with the foreign company; the farmers rely on the foreign capital and supply their produce in return (Sharma, 2019).

\section{Role of Market and emerging of Cash Crops}

Production of any crop is entirely the decision of the farmers, while the profit depends on the market's favour. There was a commercial revolution in 1861-1865 where the civil war began in North America, farmers' products were highly demanded, and it was exported nationally and Internationally. Looking back at ancient times, cash crops started with the commercialization of products such as food grains, cotton, coffee, oilseeds, rubber, cocoa, sugarcane, and tobacco. These crops play a very important role in promoting economic growth in different countries.

Initially, farmers cultivate crops for self-consumption yet later discover that they can use them as a surplus crop. From subsistence crops, farmers got the idea to commercialize their products; for example, rice, wheat, and millets are sold to those who do not cultivate yet consume these kinds of crops. As time changed, different types of cash crops were coming up, and farmers started to shift from subsistence to cash crops. Marketing of cash crops enhances economic growth; for example India, the value of cotton commercializing outside the country was over $\$ 7.4$ billion. Cash crops enhance the livelihood of people in developing countries where farmers generate income for themselves and serve food for the people who need and buy their produce (Good, 2017). The coming up of technology, education, market system, industry, and other needs of the hour influence the farmers to commercialize their crops (Johnson, 2003).

\section{Relevant of Social enterprise model: Market intermediary model}

The Market intermediary model is embedded in nature, as a social program is synonymous with business activities. To conduct any social program, it needs the support of enterprise revenue. Therefore it is comprehensive and can focus on financial and social benefits at the same time (Nicholls, 2006). The farmers are utilizing the market as an intermediary where they can sell their products and generate income to support the expenditure of any social program conducted. There are different programs and associations that create a positive impact on society. It is quite tragic for the farmers to organize any council, establish associations, raise families, conduct community development and celebrate any festivals without the support of commercial crops where they generate income by selling in the market and thus funding any social activities.

Example: Christmas is one of the most practice celebrations in the region as there is no other religion except Christianity. It brings unity, love, joy, and hope for the people. They believe in earning their livelihood through righteousness "kamai ia ka hok ka sot" the celebration helps the 
people to get together in one place where they eat and celebrate as one community. In order to organize this program, they need to donate money where they earn from selling their products and then buy food items and other equipment that enhance the social program and benefit the target population at large.

\section{Nature of study}

People of Ri-war region Mawkyrwat block are agrarian, cultivating the crops for selfconsumption and for commercialization, they used to go for marketing, selling their products twice a week, this is the reason for which the researcher explored deeply on their sources of livelihood and the way they are engaging with it. It is a fact that the people from the "War" area do not produce rice, potato, and other vegetables, which are the staple food items they eat every day. Therefore, to buy those items, they need money, and they need to generate income to buy outsider goods. In exchange for that, they are selling their products that are suitable to cultivate in their regions, such as wild black pepper, bay leaf, broom grass, areca nut, betel vine, banana, and other horticulture fruits. Some of their produce is valueless without any further processing in the factories, as it cannot be used directly. Once the transition and value addition is completed, then it can be used for any purpose. Therefore, the scenario of the study is to understand the effect of their products on their livelihood.

\section{Objectives of study}

1. To know about the marketing and cash crops farming

2. To understand the effects of cash crops on the livelihood of people in day-to-day life.

\section{RESEARCH METHOD}

\section{Types of study}

The research study is based on the qualitative method as it is exploring on the primary levels where they are practicing and enhancing the commercial crops as a source of livelihood. The qualitative method focuses on the value and impact of the product, not on the amount of the produce.

\section{Research design}

The motive of this research paper is to understand the impact of cash crops. Therefore the data collection aims at exploring information from the grassroots level as well as from secondary sources. The design is on a descriptive basis; briefly, it explains the origin, transformation, and contribution of cash crops towards people's livelihood. The paper is solely aimed at elaborating the whole scenario of commercial crops cultivation.

\section{Sampling method}

Initially, the researcher was planning to take a simple random sampling; however, being conscious of biases due to the large population in the region. The researcher shifted to homogenous sampling, which is a type of purposive sampling. The selection of sampling method was done after 
analyzing the research questions and found that they addressed a particular unit (people), specific characteristics (farmers) of a study area.

\section{FINDINGS AND DISCUSSION Impediment of Cash Crops Marketing}

The process of crops commercialization is not always an easy path; the most vulnerable are the farmers who are the backbone of the market and economic growth. They have been marginalized since the time of the British Empire; they were forced to cultivate non-food production and feed the Britain Industries. If the farmers do not cultivate cash crops, they will not be able to pay the debt taken from Moneylenders and Landlords. Directly or indirectly, farmers have to shift from food production farming to commercializing crops, and their livelihood becomes unstable; if the market is going well, they will have a good income, and if the price is low, there will be a tragedy as there is no food substitution. The evidence we can put in was the deindustrialization of the cotton industry in 1860-64; it was the shock and trend for the farmers who have abandoned cultivating rice, wheat, and jowar, bajra, and pulses. The misery occurred when the price was very low, they could not afford to support the family, and the consequence was awful. Many farmers uprooted cotton plants and burned them away. Another incident took place in India in 1866 where the famine happened in Orissa and Bengal; it has discouraged the farmers from practicing commercial crops as they could not compromise in times of emergency need. At the initial stage, the commercialization economy did not reflect a good impact on agriculture production; there was a hindrance for poor farmers to access agriculture factors such as machines, technology, fertilizer, pesticides, and other efficient means. The farmers losses their independence; they were controlled by moneylenders whom they asked for a loan to invest in agriculture and were dependent on merchants to market their produce. The dominant of moneylenders, landlord, and traders have put the farmers in distress. The advantage is taken by the British to press down the price, and other sorts of unethical acts happened in the early days. However, we could not deny that it is over; farmers in different places are still facing adverse challenges and could not remove the mask of vulnerability; it might be due to political manipulation, low rate of produce, natural disaster, and un-affordability to access upright equipment (Sharma, 2019).

\section{Origin of cash crops in "Ri-War"}

The information was collected through the survey and semi structured-interview with the elders of the region. It is said that commercializing the crops has been practised since the 1960s. Before that, people were involved in subsistence crops and the barter system. As per the information given by Mrs. Thiksilian Nonglait (82 years old), Mr. Spendar Nongsiej (68 years old), and Persis Shangdiar (50 years old), the crops has been introduced to commercialize through the initiative taken by some political leaders whose aim is to promote development by enhancing the farming. The imminent leaders who took the responsibility of innovating commercial crops are (L) Edren Syiemlieh and (L) Endro Iawphniaw, and (L) J.J.M. Nicholes Roy.

In the olden days, there was no transportation; people had to travel by walking and carrying their produce to the market; they preferred to go for border market or "hat border" rather than the capital city Shillong as it is much farther than the Indo-Bangladesh market. Back then, the barter system was taken place in the border market, and people had less information about marketing in 
Shillong. If they want to go to Shillong, they'll have to walk for $83 \mathrm{~km}$ distance and would take 2 days. On the other hand, going to the border market "Balat" takes at least 6 to 7 hours walking through the shortcut route.

Initially, people were aware of the forestry produce that might be useful in some way or the other. Therefore, the political leaders randomly took those crops, introduced them to the businessmen in the border market, and asked to select the crops that could be widely commercialized. Knowing that those crops were suitable for cultivating and could generate more income, the leaders conducted political hearings and asked the people to cultivate those crops and help with the marketing. There was no technology or information on how to cultivate those crops; however, people learned through experienced and inculcated the ideas to cultivate the crops that could be commercialized. The first crops that were introduced in the region were Wild Black Pepper or "Soh Marit Khlaw" in Khasi and Broom grass or "Synsar" these crops were introduced by (L) Mr. Edren and (L) Mr. Endro and later (L) J.J.M. Nicholes Roy introduced Bay leaf or "Sla Tyrpad".

\section{The paradigm of Cash crops in the Ri-war Region}

Farming and crop cultivation are the backbones for economic growth and sources of living for the primary sector. The varieties of cash crops which play a very important role in the region are the following;

\section{Broom Grass}

The scientific name is Thysanolaena maxima and is generally called broom grass; its utilization is to clean the house and to surround after making as a broom. It grows in a steep sloppy, and rocky area with an altitude of 5,600 ft. According to the Magazine "India Today" that was issued on 14th February 2000, some broom grass traders considered Meghalaya as a Jharu state. One of the traders by the name of Kailash Agarwal briefed his business saying that he visited Khasi Hills, particularly Ri-bhoi District, buying broom grass from the farmers in a big bundle and exporting to other states of India, selling at a retail price for household use (Sen, 2014).

Not long ago, people of Ri-war area started cultivating broom grass or Thysanolaena maxim. As per the interview with Mrs. Thiksilian Nonglait, one of the elderly people of the region, broom grass turned into cash crops in the year 1960 when some of the political leaders introduced to the businessman from Bangladesh. Since then, they started cultivating and selling to the market. However, the state government considered it as a forest product, not as a commercial one, until 20th May 2019 when the State government accepted it as a Cash Crop where people can cultivate widely along with governmental assistance. Prior to that, neither subsidies nor schemes were given to the people to enhance the production of broom grass.

According to the data collected, out of 50 respondents, 50 of them cultivate broom grass, which shows that every family is interested in generating income from these particular crops. Broom grass was being practiced as a cash crop in the region in the year 1960s; before that, no one was paying attention, and they just grow wildly in the jungle; farmers cut a bunch of it to sweep the house only and not for other purposes. The research and notification of some political leaders brought into notice to the farmers of the region that it can be cultivated and exported. Mrs. Thiksilian Nonglait, a senior citizen of 82 years, briefly explained how they used to commercialize 
in the beginning, and it is completely different from the current scenario. There was no local market, no road accessibility; farmers had to carry their produce to Mawkyrwat, the nearby town with different distances from different villages. They used to sell in a small bundle, and the business person never used a weight scale for buying broom grass. The cost of broom grass with 15 to 20 pieces per bunch was Rs.1 to Rs.2 rupees; the intermediary bought from the local market and transported it to Shillong for further exportation.

The current market standard is completely different from the early days, presently many local markets are emerging in different villages of Ri-war Mawkyrwat block, and there are roads accessible to their villages. They don't need to carry their products physically from home to market, even though they can't escape carrying from their farm to their house since there is no transportation yet. Middlemen are buying broom grass in Kg, not in a bunch like earlier; they are using weighing scale nowadays, checking the quality and buying according to that. Broom grass has two categories, one whom they plow in December and January, and the other type is the one whom they harvest in the second week of February to March; in the short term, the farmers call it "Kdait tlang" or winter broom grass and "Kdait pyrem" spring broom grass. The brooms harvested in December and January have good quality and possess a good price. The current price per Kg is Rs. 105 number one (winter broomstick) and Rs.55 number two (spring broomstick).

\section{Bay leaf (Cinnamomum tamala)}

It is a Non-Timber Forest Produce, grows in a tropical and sub-tropical region. Bay leaf cultivation is being practiced in different regions of Meghalaya that is Khasi hills Division, Jaintia hills Division, and Garo hills Division. It grows on the border of Indo Bangladesh, where the temperature is more suitable. Very often, the seeds germinate and sprout by themselves into big trees, and there are also bay leaf nurseries where farmers are planting and shifting once they are matured, knowing that they will not die if they displace them. Bay leaf is mainly used for spices, perfume, extracting oil, and Ayurvedic medicinal purpose. According to the Institute of Livelihood Research and Training convergence with Meghalaya Basin Development, they found out that the data released by International Research Forest Livelihood 2008, Meghalaya production of the bay leaf was estimated to 44,370 MT valued at Rs. 576.8 million.

Bay leaf trees can be planted with any crops in the same area; they can be grown in broomstick vicinity, black pepper farm, betel nut area, and orange farming area as well. It is a moderate size evergreen tree grown mainly in the tropical and sub-tropical areas of Meghalaya. The farmers plant the seeds as a nursery and uproot them to plan in a proper place once they are matured. Yet there are bay leaf trees that can grow by themselves when the seeds fall from the trees or even out of birds' excreta when they are consumed. It grows within the village and in the jungle as well; it provides supplementary income to the marginal farmer. The leaves are used as condiments and spice but find major application in the pharmaceutical and Ayurvedic medicine industry. People collect the raw material and sell it to the market for finished products.

The farmers are selling their bay leaf in the local market, putting the leaves inside the sack with a maximum of $42 \mathrm{~kg}$ per sack; if the sack contains more than $42 \mathrm{~kg}$, the extra amount will not be counted for the price as per the description by the sellers. Selling of bay leaf is categorized into two, one is an only leaf, no tiny branches contain, and the other is a bay leaf with tiny branches that 
can be put in. The better price is always paid to the sack with leaf alone absent of small branch. Currently, the price is Rs.16 per kg and Rs.10 per Kg for sacks of the bay leaf with tiny branches.

\section{Wild black Pepper}

There are two types of black pepper in Meghalaya and Ri-war in particular, the edible black pepper that can consume it directly or "Sohmrit bam" in khasi, it is long in shape, and small round pieces contain on its body, it is mainly used for spices. While the wild black pepper or "Sohmrit Khla" is short in size containing tiny round pieces on its body, having different tastes and smells from the former black pepper. Wild black pepper is used for the medicinal purpose for respiratory problems, cough, fever, abdominal constraints, jaundice, and urinary infection. Wild black pepper is scientifically known as Piper Longum Linn; it is also found in some parts of Assam, like Mikir Hills. It contains lots of medicinal properties, so much so that the price reaches Rs.700 per kg; it does not require any fertilizers or manure except dry leaves mulching. Very often, it grows by itself from the seeds that fell down when it got ripened or even from bird excreta who consume it (Black pepper, Northeast slow food, and Agrobiodiversity Society-nesfas, n.d.).

It is one of the expensive cash crops compared to all other crops, where the current price is Rs.710 per kg, yet it doesn't grow well and is very delicate, the favourable depends very much on good weather, not too much precipitation nor too less, if there is less rain it becomes dry and bears no fruit, and if it is too windy, it perishes and falls down before maturity.

Compared to the former crops mentioned above, farmers gather less amount of wild black pepper in a year. Out of 50 respondents, 22 farmers generate income between Rs.50, 000-/- to Rs. $1,00000-/-$ annually from wild black pepper, while the rest could generate only below Rs. 50,000 (fifty thousand).

\section{Impact of marketing}

Marketing of Cash crops is predominant in agrarian society; it improves the living standard of the farmers, promotes economic growth, and generates livelihood resources. Positively cash crops are enhancing the market system, improving farming, multiplying of produce, diversifying of crops cultivation, and management of farming equipment such as machines, high yielding crops, fertilizers, and other technology. Enabling cash crops to generate income, farmers could possess that equipment and support the family. Intercropping is one of the safest ways to practice, where farmers can cultivate food crops and non-food crops. If a non-food crop doesn't work well, farmers can support themselves with the food crops they cultivate through the help of a market intermediary.

The farmers are always concerned with the market system whether the price is going well or not. If the price of the crops is bad, it will affect the family income where they need to pay education fees, electricity bills, health care, household commodities, and other expenditures. There is a problem even to getting rice, sugar, tealeaf, salt, dal, potato, and other edible things, as it is not grown in Ri-war. Farmers need to sell their produce and buy the ones, which they don't have. Therefore, in order to prevent the crisis, they always cultivate food crops, particularly tapioca, which is one of the staple foods that they can use as a meal in case they don't have money to purchase rice. 


\section{Data Transcription}

The data has been accumulated from five small villages with a maximum of 30 to 40 households in each village. They are under the jurisdiction of the South West Khasi Hills District Mawkyrwat block. The data was collected through the survey, semi-structured interviews, conference calls, and observation.

\section{Analyzing and data interpretation}

The data collected is based on the objectives of the research and divided into two parts: -

\section{The first objective, To know about the marketing and cash crops farming ;}

\section{Family size}

The aim of inquiry about the family size is to know the capability of agriculture where it can support the total strength of the family either partially or fully apart from other resources. It is found that the people in the region did not practice family planning and believe that the more children they have, the more the blessing they attain from God. On the other hand, the more people they have in the family, the better it is to work on the farm where they don't need to hire labour yet they can work by themselves. According to the data collected they said if five people work for one week in planting the crops, they can finish the harvesting in three days, and the reason is due to the low level of production in the vicinity. Yet they did not face any financial crisis if the market was good and stable; they had sufficient crops to support the family.

\section{Market management}

The survey shows that the majority of the people in Ri-War are farmers and managing their own trading; each and every farmer has the information about marketing, there is no other choice or way around to escape from marketing, they have to sell their own produce in other to buy other goods which they don't have. It is totally dependent on their own skills and techniques without any professional training in marketing. They have been born and brought up as a farmer and inculcate the traditional knowledge to practice agriculture and raise up to adapt to the market standard and support themselves. There was a transition from subsistence crops to cash crops or from a barter system to a cash system. The practice of commercializing brought adverse changes to the style of farming and even the types of crops cultivated. In the early days, they cultivated the crops, which they could use directly without any further transformation or industrial help, for example, yam, banana, orange, tapioca, millets, areca nut, and betel vine. They used to exchange what they had with what they didn't have, like clothes, shoes, rice, soap, and others.

\section{Major cash crops}

The data collected was found that the traditional crops were shifted partially to the three major commercial crops those are broom grass, bay leaf, and wild black pepper. The original crops practised by ancestors are not completely eliminated or forgettable, yet it is still practiced even these days. 


\section{Organic farming}

It is inspiring to know that people are practicing organic farming throughout their life yet it is unfortunate to know that no one recognizes their product quality. The price is being pressed down by local business people in an informal market standard. There is no price fix for their produce; the good price of their produce depends on the days, not on the quality. The farmers said that they don't know what organic produce is since no one is renowned nor talk about it in the market. They said that there are times where they have to leave their products in the market no matter how good they are, the price is too low, to take back is too far as they have to walk on foot for one to two hours.

\section{Problem facing}

After exploring on the transition of cash crops, there was also a question on the major problems faced by the farmers. The most prevalent problems as per the query are:

1. lack of government support,

2. low level of market standard

3. instability of prices and domination of big businessman

4. low cost of production,

5. infertility of the soil,

6. financial problems and

7. Lack of technologies to improve farming and enhance income.

It is surprising to know that there is no help from the Government so far, and to support this data as per the farmer's information; I went to enquire from different offices in the district headquarter. Asking about the current schemes available and the one that has been implemented in Ri-war area of Mawkyrwat block, some scheme like MIDH is there, but it doesn't cover all the farmers in the region. The only Governmental scheme that is currently implemented and covers all the farmers is Pradhan Mantri Kisan Samman Nidhi (PM-KISAN). However, up to the date I did my survey, only 50\% have received the money in their account, the estimated amount of Rs. 6000-/per household annually and given in three installments. The scheme was launched in Meghalaya in February 2019, in ICAR research centre Umiam, Shillong Meghalaya.

\section{Case study on a farmer who practices Entrepreneurship}

There was an interaction with Mr. Spendar Nongsiej, one of the prominent farmers and moneylenders of the region. The income he generated from cash crops he invested in constructing houses for renting and giving loans to the people, he is one of the successful farmers in the region having a good amount of cash crops assets. While interviewing, asking about his technique of farming, he said that he follows the traditional style even though some researchers from the Agriculture sector teach a new technique, yet he refused to follow as he has learned enough from his experiences. He knows the appropriate time to plan and what types of crops in which kind of land, and how to take care of it. However, due to his family problems, the death of his wife, and the mental challenges of his children, he could not maintain the farming practice as before. 


\section{The second objective, to understand the effect of cash crops on the livelihood of people in day-to-day life;}

As it has been described earlier about the members in the family and its livelihood support, we acknowledge through the information given by the farmers where they admit that horticulture is their main supporter. However, in the second part of the survey, I tried to find out if there are any other sources of income apart from farming. It was found that people are also interested in rearing pigs and chickens. They don't want to keep goats and cows as there is no grassland and are afraid that they might destroy their crops. The scheme MGNREGA is one of the main supportive factors to compromise in the un-employ season. Lots of infrastructures are being constructed through MGNREGA, such as toilets, footpaths, walking bridges, poultry shed, pig shed, drainage, and water tanks. Within the villages, there are people who sell groceries in their houses without establishing any proper shop. In a local market that happens twice a week, people in the region used to sell their local produce, and some others are opening tea stalls, selling vegetables, clothes, and others where they export from outside. Asking about their feedback in putting fair price shop in the village, they said that selling commodities to the people from the same village they tend to take advantage and borrow the items without paying on the spot. It is not easy to support their business if the customers are delaying paying their due on time.

Apart from the above sources of income, people are also selling timber, medicinal plants, river fish, bamboo craft, and some other forestry produce. These are the additional sources where they compensate in the absence of commercial crops, as they are not available throughout the year.

\section{Ethical Consideration}

Keeping the ethical conduct of the research, the objectives of the study was being introduced diligently and making sure that the respondents did not get aggravated or misunderstood with the questions that were asked during the survey and interviewed. Permission was always asked from the farmers whether they were willing to share their information or not. In certain circumstances, it is needed to get their name, age, and gender to support the information collected, yet the researcher did not disclose their names without getting their permission. Ethical research helps to avoid biases where the researcher tends to assume the information without proper investigation, yet keeping the ethic in mind, the researcher maintains a qualitative investigation, proves it, and acknowledges it for recording.

\section{CONCLUSION}

Ri-war, a sub-tribe of Khasi in Meghalaya is interdependent with other sub-tribes in terms of commercialization and availing food items; different subgroups practice different types of farming according to the location and proficiency of temperature. Crops that grow in the plains region are not suitable to plant in hilly areas. Ri-war people are located on the borderline with Bangladesh, where the topography contains imminent hills and steep valleys.

Marketing of crops plays a very important role for the particular sub-tribe (War); it is not because of their desire or interest but due to the location where they live in. Their stable food is mainly rice, and they couldn't cultivate it. Therefore they have to sell their produce to purchase rice.

Apart from commercialization, the barter system is not extinct in the region. The War people tie a friendship called "Marngap" (in the local name) with the people living in the plain areas who 
cultivate rice, potato, vegetables and exchange with their crops such as tapioca, betel vine, orange, pineapples, etc., this is done through the role of marketing. "Marngap" is not only meant for exchanging food items but for selling products as well. For instance, a farmer from the plain area wants to buy good quality tapioca or banana, orange, betel nut, or betel vine; he/she will ask their friends from War region to bring how much they need.

However, the need for the hours compels the farmers to sell their produce, even the ones whom they can consume for themselves. Marketing the farmer's produce is rampant, the data showed the numbers of people cultivating tapioca, yam, and fruits are drastically decrease and possessing higher rate in farming cash crops such as broom grass, bay leaf, and wild black pepper, physically and mentally aiming at generating income through farming activities.

The need of the hour to achieve livelihood sustainability is Governmental attentions to improving the market standard for better sale and supplications of farmers' produce. On the other hand, to recognize their organic farming and encouraging eco-friendly agricultural activities, in that way, it will help to save the land from overexploitation and promote the security of farming for future generations.

\section{Limitation of data collection}

1. No written data was found on the origin of cash crops in the region: the information was shared verbally from generation to generation.

2. Time constrains: Covid-19 creates havoc in every sector; collecting data is not always an easy method, there are hindrances in time management and meeting people.

3. Challenges to meet the officers-in-charge who can give secondary data about the agriculture practices of the people in the region: despite pandemic, there are some days where government offices are opened; however, to meet the officers-in-charge is not an easy way, it might be due to their health concern or abiding by rules and protocols.

\section{REFERENCES}

C.Babu, S. (2009). Food Security, Poverty and Nutrition Policy Analysis. Washington: Academic Press, New York USA.

Good, A. (2017). Cash Crop blog Series Introduction. Retrieved June 18, 2021, from https://globaledge.msu.edu.

Johnson, F. (2003). Cash Crops: definition and history. Retrieved June 18, 2021, from https://study.com.

Nicholls, A. (2006). Social Entrepreneurship . New York: Oxford University Press INC.

Sen, A. (2014, February 14). broom - India today . Retrieved June 15, 2021, from https:/www.indiatoday.in: https:/www.indiatoday.in.

Sharma, P. (2019). commercialisation of agriculture: meaning, phases and consequences/Indian economic History. Retrieved June 17, 2021, from www.historydiscussion.net. 